\title{
The Effects of Task-based Approach on Speaking Anxiety among ESL Low Proficiency Diploma Students
}

\author{
Viji Ramamuruthy \\ Universiti Tunku Abdul Rahman, Malaysia
}

Copyright $\mathrm{C} 2019$ by authors, all rights reserved. Authors agree that this article remains permanently open access under the terms of the Creative Commons Attribution License 4.0 International License

\begin{abstract}
The objectives of this study are to determine the presence of speaking anxiety among ESL learners, to investigate the relationship between language anxiety and speaking skills and to determine the effect of task-based approach on learners' speaking anxiety. This quasi-experimental investigation was done on a total of 30 ESL low proficient diploma learners, who were in the age range of 18 to 24 . These purposive samples were given questionnaire to support the first research question as it tests the presence of speaking anxiety. This questionnaire is framed as per the model of Foreign Language Classroom Anxiety Scale (FLCAS) which was designed by Horwitz et al. (1986). The pre-test and post-test, which were adapted from IELTS speaking test examples, were used to determine the effect of task-based approach. Task sheets containing pictures related to automobile, routine, events and processes were prepared by the researcher to conduct the seven weeks of programme. The findings revealed that anxiety exists among the learners in terms of communication apprehension, English language class anxiety and fear of negative evaluation. The more anxious the learners became, the lower the grades were achieved. The use of task-based approach throughout the intervention has given positive effect on the grades achieved in the post-test.
\end{abstract}

Keywords Task-based Approach, Speaking Anxiety, ESL Low Proficiency Learners

\section{Background of the Study}

Due to the significant advancement in the field of the automotive, graduates are not only expected to be skillful in solving technical and industrial problems, but also need to be proficient in communicative skills too. According to Tartar (2005), active classroom participation plays a vital role in the success of language learning.

When a student becomes a passive speaker or utters minimal words in a discussion, it is clear that the student is not learning well, and teachers and educators may wonder why (Hamouda, 2013). It is a common phenomenon, which takes place in a teaching and learning environment. There may be many causes of this type of behaviour. According to Horwitz, Horwitz \& Cope (1986) and in fact in the most recent study by Amorim (2013), second language anxiety can be one of the most affective variables, which hinders the development of the learners' oral performance, and this leads them to be passive speakers.

\section{Statement of Problem}

Extensive research has been done by the past researchers to explore pedagogical approaches since early 1980s in the field of Second Language Acquisition (SLA). Researchers such as Mamhot, Martin \& Masangnya (2013), Andrade and William (2009), Worde (2003), Liu (2007), Chan and Wu (2004), Cheng (2004) and Horwitz et al. (1986) had proven the presence of language anxiety among EFL and ESL learners. Indeed, Arnaiz's (2012) research findings revealed that lower grade students tended to have higher anxiety level, and lower level students tended to be more anxious. All these research were carried out to find out the presence of anxiety, factors contribute to language anxiety, ways to reduce anxiety and effects of anxiety on language learning.

Although, there were many studies done on anxiety, issue related to anxiety and specific pedagogical approach which helps ESL learners to cope with anxiety have not got the same degree of attention. Whereas, educators and teachers believe that anxiety has an undeniable impact on learners' speaking skills. These difficulties originated from a more deeply rooted problem, which is caused by certain anxieties that the students are experiencing when they are in English language classroom (Lucas, 2011). Generally, this is a common phenomenon in Malaysian higher learning institutions, especially in International College of Automotive. Business English 1 and 2 are offered for all the students who are in the year 1 semester 1 and 2 respectively. Reading and writing skills are more 
emphasised in Business English 1 and 2, as they are tested in the final examinations. Since, there is no particular assessment to test oral competency of these students, very little emphasis is given for speaking skills.

This puts the English lecturers or educators in a difficult situation as they will be at fault if there are any failures in the classroom. Needless to say, these failures usually possess low proficiency level, and they are encountering difficulties in learning English for specific use. Since, there is not much opportunities created for the students to practice the language verbally, most low proficiency learners lack confidence and often develop speaking anxiety. As such, lecturers or educators should design lessons, activities and materials that will best address the strategies that can be effectively utilised by these learners to cope with anxieties.

\section{Purpose of Study}

The intention of this study is to contribute more to the local literature related to language anxiety by emphasizing on speaking skills and pedagogical approach. Studies in the past focused on the presence, factors, effects and ways to reduce or get rid of speaking anxiety.

But, the relationship between language anxiety and oral competency of ESL and EFL learners still remains unidentified (Mamhot et al. 2013). In fact, the relationship between language anxiety and teaching styles or strategies remains as a question mark as well (Mamhot et al. 2013). Although these unidentified issues are highlighted based on a study conducted in Philippine, it is applicable to a non-native country like Malaysia too since we share the same scenario in mastering English language proficiency.

Teachers and curriculum developers are urged to design curriculum or lessons which best suits learners' needs (Musa, Lie and Azman 2012). Indeed, Musa et al. (2012) suggested that investigating the pedagogical practices of teaching English in Malaysia would give a hand to the Malaysian low proficiency or anxious learners in enhancing their language proficiency to handle their social lives.

Thus, it is crucial to investigate pedagogical approaches which educators could adopt in order to improve learners' speaking skills and reduce anxiety.

\section{Research Objectives}

The objectives of this study are:

1. to determine the presence of speaking anxiety among ESL learners.
2. to investigate the relationship between language anxiety and speaking skills.

3. to determine the effect of task-based approach on learners' speaking anxiety.

\section{Research Questions}

This research will be conducted in order to find answers for the following research questions:

1. To what extent do the ESL learners experience speaking anxiety?

2. Is there any relationship between language anxiety and speaking skills?

3. To what extent does task-based approach affect learners' speaking anxiety?

\section{Literature Review}

\subsection{Concepts of Anxiety and Fear}

From the SLA perspective, Gardner \& MacIntyre (1993) define language anxiety as an unpleasant worry experienced when a circumstance requires the learner to use a second language in which the learner is not fully proficient. Chan and $\mathrm{Wu}$ (2004) define anxiety as a psychological concept while Spielberger (1966) describes it as "subjective, consciously perceived feelings of apprehension and tension, accompanied by or associated with activation or arousal of the autonomic nervous system" (p.15). In other words, anxiety is an unpleasant feeling that over rides the excitement of a learner and eventually causes worries about achieving his or her desires. When the emotion of anxiety develops to be inappropriate to a particular situation, the feeling of fear takes place within a learner.

\subsection{Theoretical Framework}

Affective filter hypothesis is first proposed by Dulay and Burt (1977) and is incorporated by Krashen as one of his five input Hypotheses in 1985. Krashen claimed that people acquire second languages only if they receive comprehensible input, and if their affective filters are low enough to allow the input 'in'. In his theory, one of the affective filters is anxiety. Anxious learners have a high affective filter, which prevents acquisition from taking place. Hence, the theoretical framework in figure 1 was formed based on the two main variables which are closely related to anxiety; pedagogy as the independent variable and speaking anxiety as the dependent variable. 


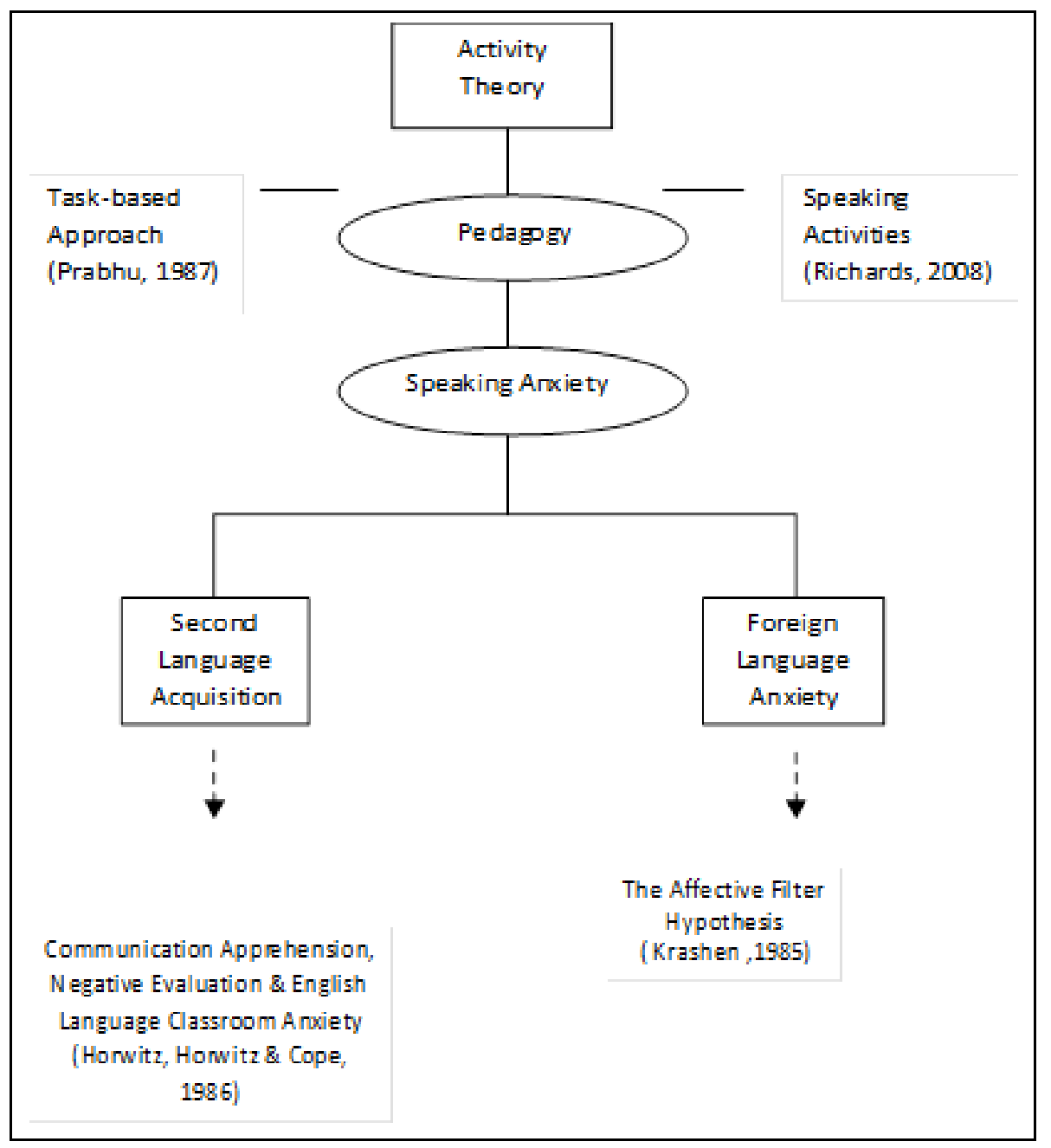

Figure 1. Theoretical Framework

\subsection{Anxiety in Language Learning: Early Studies}

As the first theory that emphasises the specific nature of foreign language anxiety, Horwitz, Horwitz and Cope's theory of foreign language anxiety, has been used in many studies in the field of anxiety. The components of foreign language anxiety have been identified (Horwitz, et al., 1986; MacIntyre \& Gardner, 1989) to narrow down this concept into researchable issues such as fear of negative evaluation, test anxiety and communication apprehension or speaking anxiety. These are the ultimate factors, which lead to the creation of anxiety among language learners.

According to Watson and Friend (1969), and Horwitz et al. (1986), fear of negative evaluation can be defined as "apprehension about others' evaluations, avoidance of evaluative situations, and the expectation that others would evaluate one's self negatively" (p.128). Mamhot (2013) stated that the apprehension that the learner feels is more of the external factor (i.e., what other people think about him/ her than what he/ she thinks about him/ herself).

On the other hand, foreign or second language learners experience more language anxiety in highly evaluative situations (Daly, 1991). In fact, some learners do experience such anxiety in a non-evaluative situation, because they perceive any opportunity for communication in a foreign or second language as an evaluative situation (Horwitz et al. 1986). Whilst in the recent article, Gomari and Lucas (2013) stated that, test-anxious learners impractically expect themselves to get perfect grades in tests and, to their minds any score below perfect is equal to failure.

However, this study focuses on the last component which is communication apprehension or speaking anxiety. Generally, communication apprehension refers to a type of anxiety experienced in interpersonal communicative settings (McCroskey, 1987) which is obviously relevant to second or foreign language learning contexts. For instance, when the learners have little control of the communicative situation, and both the teachers and peers constantly monitor their performance (Horwitz, et al., 1986), communication apprehension takes charge of the inability of the learners in understanding others and make themselves understood. Hence, this causes negative self-perceptions (MacIntyre \& Gardner, 1989).

To be specific, Mamhot et al. (2013) carried out a comparative study on the language anxiety of ESL and 
EFL learners. The finding of this research says that unlike EFL learners, ESL learners do suffer language anxiety. A few suggestions were given for teachers to reduce the level of anxiety among learners. One of the suggestions is, teachers should focus on eliminating low self-perception. Second, teachers have to refer to learners' cultural background before assigning tasks. Third, teachers are to create conducive and friendly learning environment.

\subsection{Factors and Causes Contribute to Language or Speaking Anxiety}

Horwitz et al. (1986) were the first to carry out a detailed examination of the dynamics of foreign language anxiety by creating and using the foreign language classroom anxiety scale (FLCAS). Young (1990), following Horwitz, developed a questionnaire to examine more systematically the types of in class, speaking-oriented practices that evoke anxiety from second language learners.

Mak (2011) investigated factors contributing to the speaking-in-class anxiety of a group of 313 Chinese ESL first year university students in Hong Kong. The findings revealed five factors which are leading to the group's speaking-in-class anxiety. The five factors include: (1) speech anxiety and fear of negative evaluation; (2) uncomfortableness when speaking with native speakers; (3) negative attitudes towards the English classroom; (4) negative self-evaluation; and (5) fear of failing the class/ consequences of personal failure. In addition, survey results show that speaking in front of the class without preparation, being corrected when speaking, inadequate wait-time not being allowed to use the first language in a second language class were also identified by the respondents as important factors leading to speaking-in-class anxiety. Besides that, performing in front of the class, speaking without preparation and focusing on forms are the type of activities which cause high anxiety among students (Abdullah \& Rahman, 2010). In certain circumstances, gender and acculturation do play some roles on language anxiety levels as the variables correlated with language anxiety (Cheng, 2012).

\subsection{The Effects of Anxiety}

The effects of anxiety on foreign language learning have been studied since the 1970s (Scovel, 1978) as its presence affects learners' participation in the classroom. A comparative study on the language anxiety of ESL and EFL learners which was conducted by Mamhot et al. (2013) showed that the most affected language process for both EFL and ESL learners is the output.

In fact, according to McIntyre \& Gardner (2000 in Tanveer, 2007, p.23), anxiety at the output stage might hinder the students' ability to speak in the target language. Moreover, according to Mak (2011) negative attitudes can affect oral performance and grades when meeting compulsory requirements to speak and contribute to role-plays and discussions in a positive manner.

It was found that, students with a high level of anxiety mostly perform badly during oral performance. At the beginning stage, the students become uncomfortable and feel nervous when they experience language anxiety. Consequently, the level of test anxiety increases when level of speaking anxiety increases, and it eventually reduces the students' motivation to learn a language (Chan Swee Heng, Ain Nadzimah Abdullah \& Nurkarimah Binti Yusof ,2012). Some students even prefer to remain silent and unwilling to participate in speech communication in class as a result of anxiety (Diao \& Shamala ,2013)

Needless to say, English language anxiety affects the learning process negatively. As a result, students learning process gets disrupted.

\subsection{Pedagogy in Context: Activity Theory}

The Activity Theory was first developed by Vygotsky in 1978, and it was further explained by Leontiev (1981). Then it was related to a theory of pedagogy as an activity system by Engestrom (2005).

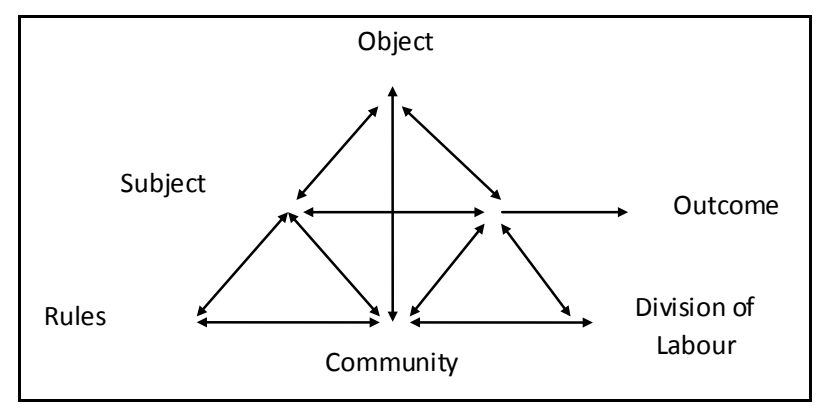

Figure 2. Third generation Activity Theory

In order to achieve a specific outcome, the subject(s) acts on the object through mediating artefacts. The position of subject is influenced by the rules of the system, his/ her community and division of labour (Daniels, 2001; (Engeström, 1991; 1987). Engeström (2005) viewed pedagogy by incorporating the following elements;

1. Subject: The teacher is regarded as the subject and believes that children learn through active engagement.

2. Mediating artefact: Tools viewed as resources which mediate thought during interaction between the subject and the context within an activity.

3. Object: It is viewed as "the 'raw material' or 'problem' space' at which the activity is directed and which is moulded and transformed into outcomes with the help of physical and symbolic, external and internal mediating instruments, including both tools and signs" (Engestrom,1987, p.79).

4. Rules: In Activity Theory, rules are driven by the subject's action in terms of norms, conventions and social interactions of the classroom. In other words, the teacher leads the students by establishing instructional rules and rules of social order. 
5. Community: The community includes the teacher and the students who work together to complete a task.

6. Division of labour: This refers to the responsibilities of the teacher and the students in the classroom. To be specific, the teacher's role is to teach and the students' roles are to learn.

Engeström's (2005) notion of activity system incorporates a methodology for studying task-based approach as it clearly defines the role of the teacher and students and the influence of instruments/ tasks in achieving desired outcome.

\subsection{Pedagogical Implication: Task-based Approach (TBA)}

Ellis (2003) believes that the same task results in different kinds of activities when performed by different learners, and it can result in different activities when performed by the same learners at different times too. This is because whenever individuals carry out a task, they 'construct' the activity in terms of their aims and goals, which differ from each other.

Besides that, Eliss (2003) believes that a task is a tool that guides learners to engage in certain types of information-processing activities that are believed to be essential for effective language use and/or for language acquisition from some theoretical perspectives. Ellis (2003) also provides a composite definition which is as follows:

"A task is a work-plan that requires learners to process language pragmatically in order to achieve an outcome that can be evaluated in terms of whether the correct or appropriate propositional content has been conveyed."

On the other hand, Nunan (2006) defined a task as a piece of classroom work which involves learners in an understanding, directing, producing or interacting way in the target language while the learners' attention is focused on activating their grammatical knowledge to express meaning rather than to manipulate form.

In the perspective of Socio Cultural Theory (SCT), it is not tasks themselves that create the context for learning, but it is the way participants carry out the task. As such, the task is simply a device that can be used by the participants for the teacher to identify where assistance can be profitably provided in order to enable appropriate ZPDs to be created.

Azabdaftari (2013) stated that upon reading Vygotsky (1978) and literature on Socio Cultural Theory (SCT), it has become clear that there are many points of connection and compatibility with Task-based Language Teaching (TBLT). TBLT is one of the approaches to language learning which proposes 'learning by doing' (Moore, 2018). According to the researcher, there are three points TBLT and SCT share which include: an attempt to re-contextualize the classroom, the focus of activity or tasks as a place for studying and developing language, and a focus on meaning.

Various designs of task-based lessons have been proposed by researchers such as Estaire and Zanon (1994), Lee (2000), Prabhu (1987), Skehan (1996) and Willis (1996). All of them have three common principal phases; pre-task, during task and post-task. The pre-task is meant to help to create a good atmosphere for learning without anxiety. Whilst, 'during task' offers learners the opportunity to use the target language in order to carry out the task. The last phase is the post-task which is for language focus.

In summary, research on language anxiety suggests two treatment phases to successfully cope with language anxiety. These phases first focus on improving speaking skills and then are directed towards reducing speaking anxiety (Vizayaletchumi, 2012). Although many researchers have studied about Task-Based Approach (TBA) and anxiety, there is not any research done to investigate whether TBA reduces ESL learners' anxiety in using English as medium of oral communication.

\subsection{Task- based Approach via Speaking Activities}

Basically, language teaching tasks should serve as a tool that relieves the language learner from consciously focusing on language forms and help him to focus on the ways of conducting natural verbal interactions with the other learners who engage in the same task. Indeed, task-based approach provides learners with authentic and meaning-based materials, real-life interactive activities and motivating feedback (Hadi, 2013).

Richards and Rodgers (2011) believe that authentic materials are an important part of task-based activities and can come from a wide variety of sources (p. 13). They can be obtained by exploring authentic materials for English language teaching such as human interest stories, important current events, games, popular films and literature (Gomari and Lucas 2013). It also provides actual language use specifically in an Asian country like Malaysia, where learners rarely have the possibility of using English language outside the classroom.

To be specific, Richards (1990) stated that indirect approaches create conditions for oral interaction through group work, task work and other strategies. Similarly, task-based approach promotes authentic situations indirectly in the ESL classrooms. Richards (2008) designed three types of speaking activities which help the ESL learners to improve their speaking skills. They are categorised as (1) interaction, (2) transaction and (3) performance.

According to Richards (2008), 'interaction' can be done in a formal or informal setting. It focuses on participants and their social needs. Generally, people exchange greetings, engage in small talk, recount past experiences and give compliments when they meet. The second type of activity is 'transaction' which focuses on the message. 
Activities such as asking someone for direction, giving instructions to change car tyres, ordering food from a menu in a restaurant and other problem solving activities mainly focus on giving and receiving information. On the other hand, the third type of speaking activity focuses on 'performance'. This refers to activities which require participants to have a generic structure and formal language use in delivering information.

\subsection{Methodology}

\subsubsection{Research Design}

This study was done based on quasi-experimental design. A single group was used throughout treatment (Brown and Rodgers, 2002). Quantitative method was used to analyse the data in order to determine the presence of speaking anxiety, the relationship between language anxiety and speaking skills as well as the effects of task - based approach towards speaking anxiety.

\subsubsection{Population}

International College of automotive (ICAM) located in Pekan, Pahang. It offers diploma programmes for Faculty of Business and Management and Faculty of Engineering and Technology. The Samples were chosen from a total population of 150 , semester one students who registered for diploma programmes.

\subsubsection{Participants}

The investigation was done on only one group of ESL low proficient diploma learners who were in the age range of 18 to 24 . A total of 30 students participated in this study. The sampling was made based on the participants' Sijil Pelajaran Malaysia (SPM) English results. Those who scored grade $\mathrm{C}$ and below were advised to undergo a seven-week Intensive English Programme.

\subsection{Instruments}

\subsubsection{Questionnaire}

These purposive samples were given questionnaire to support the first research question as it tests the presence of speaking anxiety. This questionnaire was framed as per the model of Foreign Language Classroom Anxiety Scale (FLCAS) which was designed by Horwitz et al. (1986). Only 20 statements out of 33 which are closely related to speaking anxiety and English classroom anxiety were adapted from the original version. The phrases such as 'foreign language', 'language class' and 'language teacher' were substituted with 'English language', 'English language class' and 'English language teacher' respectively.

\subsubsection{Pre and Post-test}

The same pre-test which was adapted from IELTS speaking test examples was used for post-test to determine the effect of task-based approach. IELTS speaking evaluation form was adapted to assess learners' speaking skills. The assessment included fluency and coherence, lexical resource, grammatical range and accuracy and pronunciation.

\subsubsection{Task-based Activities}

The Intensive English Programme was conducted for seven weeks. It was handled by the researcher for 2 hours from Monday to Friday. The participants spent a total of 70 hours to complete the programme. They were asked to use English throughout the programme. Task sheets contained pictures related to automobile, routine, events and processes were prepared by the researcher to conduct the seven-week programme.

These task sheets were designed based on Richards' (2011) three types of speaking activities: interaction, transaction and performance.

\subsubsection{Data Collection Procedure}

The samples were required to sit for a pre-test and undergo a seven-week Intensive English Programme. Questionnaires were distributed to the samples to determine the presence of anxiety. Task-based approach was used to run the seven-week programme. Variety tasks were used to encourage participants to use target language in the classroom. At the end of the programme, participants were required to sit for a post-test.

\subsubsection{Data Analysis Procedure}

The data analysis was done quantitatively. SPSS was used to generate statistical results for the three main components of anxiety: speaking anxiety, English language anxiety and negative evaluation. Paired T-test was used to determine Mean and Standard deviations of language anxiety experienced by ESL low proficiency students in speaking English.

The data collected upon conducting pre and post-test indeed was helpful to identify the correlation between anxiety and speaking skills. The identified correlation coefficient showed whether there is a positive relationship between the two variables or vice versa as well as the level of significance.

Besides that, the effects of task-based approach on reducing anxiety of ESL low proficiency learners was identified by looking at the statistical difference between the means of "without" and "with TBA" at the significant level of $1 \%$.

\subsubsection{Data Analysis}

Table 1. Language spoken by participants at home

\begin{tabular}{c|c|c}
\hline Gender & Number & Percent \\
\hline Male & 28 & 93.33 \\
\hline Female & 2 & 6.67 \\
\hline Total & 30 & 100.00 \\
\hline
\end{tabular}


As shown above in Table 1, a total of 28 male and 2 female Malay students participated in this study and all of them use 'Malay' language as a medium of communication at home.

In order to answer the first research question, the 20 statements were categorized into 3 categories of anxiety such as communication apprehension, English class anxiety and fear of negative evaluation (Horwitz, Horwitz \& Cope, 1986). The responses of participants were interpreted using 5 point interval; agree, strongly agree, neither agree nor disagree, disagree and strongly disagree. These statements were analysed based on the classification which was done by Al-Sibai (2005) and (Lucas, 2011) in their investigations related to English language anxiety. The statements were divided into three categories, and they were then classified into agreed or strongly agreed and disagreed or strongly disagreed as shown in the tables below.

\subsubsection{Speaking Anxiety / Communication Apprehension}

Participants who agreed or strongly agreed for the statements 1, 5, 15,16 and 17 and disagreed or strongly disagreed for statements 8,11 and 20 proved the presence of communication anxiety.

Table 2. Agreed or Strongly Agreed

\begin{tabular}{c|c|c|c|c|c}
\hline No & Statements & $\mathrm{N}$ & $\%$ & $\mathrm{M}$ & SD \\
\hline 1. & I never feel quite sure of myself when I am speaking in my English language classroom. & 20 & 67 & 2.23 & 0.626 \\
\hline 5. & I start to panic when I have to speak without preparation in English language class. & 21 & 70 & 2.30 & 1.088 \\
\hline 15. & I feel very self-conscious about speaking English language in front of other students. & 20 & 67 & 2.17 & 0.699 \\
\hline 16. & I get nervous and confused when I am speaking in my English language class. & 22 & 73 & 2.17 & 0.699 \\
\hline 17. & I get nervous when I don't understand every word the English language teacher says. & 20 & 67 & 2.43 & 1.858 \\
\hline
\end{tabular}

The table 2 above shows statements, which were agreed or strongly agreed by the respondents. Out of 30 participants, 20 of them agreed to the first question. In other words, $67 \%$ of the participants with the mean of $2.23(\mathrm{SD}=0.626)$ never feel quite sure of themselves when they speak in English.

Besides that, $70 \%$ of them with a mean of $2.30(\mathrm{SD}=1.088)$ agreed that they start to panic when they have to speak without preparation. 20 participants admitted that, they feel very self-conscious about speaking English language in front of other students. The mean and standard deviation obtained for this statement are 2.17 and 0.699 respectively.

In addition, $73 \%$ of the participants with a mean of $2.17(\mathrm{SD}=0.699)$ conceded that, they get nervous and confused when they speak in English language class. "I get nervous when they do not understand every word the English language teacher says" stated the highest mean which is $2.43(\mathrm{SD}=1.858)$.

Table 3. Disagreed or Strongly Disagreed

\begin{tabular}{|c|c|c|c|c|c|}
\hline No & Statements & $\mathrm{N}$ & $\%$ & M & SD \\
\hline 8. & I would not be nervous speaking the English language with native speakers. & 20 & 67 & 3.67 & 0.606 \\
\hline 11. & I feel confident when I speak in English language class. & 19 & 63 & 3.83 & 0.747 \\
\hline 20. & I would probably feel comfortable around native speakers of English language. & 24 & 80 & 3.80 & 0.761 \\
\hline
\end{tabular}

The Table 3 above shows the statements which were disagreed or strongly disagreed by the participants. A total of $67 \%$ of the participants with a mean of $3.67(\mathrm{SD}=0.606)$ stated that, they would be nervous speaking the English language with native speakers by disagreeing the statement. Furthermore, $63 \%$ of them with a mean of $3.83(\mathrm{SD}=0.747)$ confessed that, they do not feel confident when they speak in English class, and $80 \%$ of the participants with a mean of 3.80 ( $\mathrm{SD}=0.761$ ) would not feel comfortable around native speakers of English language.

Overall, an average of $69 \%$ of the participants agreed or strongly agreed that speaking anxiety or communication apprehension exists among them. The presence of anxiety is proven based on the responses received for the above statements in the questionnaire.

\subsubsection{Presence of English Class Anxiety}

On the other hand, the presence of English class anxiety among the participants was identified based on the agreed or strongly agreed statements of number 2, 3, 6, 10 and 18 and disagreed or strongly disagreed statement of number 12 . 
Table 4. Agreed or strongly agreed

\begin{tabular}{c|c|c|c|c|c}
\hline No & Statements & $\mathrm{N}$ & $\%$ & $\mathrm{M}$ & SD \\
\hline 2. & I often feel like not going to my English language class & 21 & 70 & 2.20 & 0.925 \\
\hline 3. & It frightens me when I don't understand what the teacher is saying in English language & 23 & 76.6 & 2.17 & 0.747 \\
\hline 6. & In English language class I can get so nervous I forget things I know. & 22 & 73.3 & 2.23 & 0.728 \\
\hline 10. & Even if I am well prepared for English language class I feel anxious about it. & 18 & 60 & 2.47 & 0.730 \\
\hline 18. & I feel overwhelmed by the number of rules I have to learn to speak English language. & 15 & 50 & 2.60 & 0.968 \\
\hline
\end{tabular}

The table above shows that, $70 \%$ of the participants with a mean of $2.20(\mathrm{SD}=0.925)$ often feel like not going to their English language class and $76.6 \%$ of the participants get frightened when they do not understand what the teacher says in English.

The mean value and standard deviation recorded for this statement are 2.17 and 0.747 respectively. The majority of the participants with a mean value of $2.23(\mathrm{SD}=0.728)$ admitted that they forget things they know when they get so nervous in English language class. Even they are well prepared for English class, a total of $60 \%$ of the participants still feel anxious about it, and $50 \%$ with a mean value of $2.6(\mathrm{SD}=0.968)$ feel overwhelmed by the number of rules they have to learn to speak English language.

Table 5. Disagreed or Strongly Disagreed

\begin{tabular}{c|c|c|c|c|c}
\hline No & Statements & $\mathrm{N}$ & $\%$ & $\mathrm{M}$ & $\mathrm{SD}$ \\
\hline 12. & I don't feel pressure to prepare very well for language class. & 19 & 63 & 3.50 & 1.106 \\
\hline
\end{tabular}

Whilst the table 5 above illustrates that, $63 \%$ of the participants or 19 participants admitted that they do feel pressure to prepare very well for language class by disagreeing to the statement above. The mean recorded for this statement is 3.50 and standard deviation is 1.106 .

\subsubsection{Negative Evaluation}

Participants, who agreed or strongly agreed for statements 4,7,9,13,14 and 19, determined the existence of fear of negative evaluation.

Table 6. Agreed or Strongly Agreed

\begin{tabular}{|c|c|c|c|c|c|}
\hline No & Statements & $\mathrm{N}$ & $\%$ & M & $\mathrm{SD}$ \\
\hline 4. & I keep thinking that the other students are better at speaking than I am. & 19 & 63 & 2.37 & 1.129 \\
\hline 7. & It embarrasses me to volunteer answers in my English language class. & 21 & 70 & 2.10 & 1.029 \\
\hline 9. & I get upset when I don't understand what the teacher is correcting. & 20 & 67 & 2.37 & 1.033 \\
\hline 13. & I can feel my heart pounding when I am going to be called on in English language class. & 18 & 60 & 2.57 & 1.073 \\
\hline 14. & I always feel that the other students speak English language better than I do. & 20 & 67 & 2.33 & 1.028 \\
\hline 19. & I am afraid that the other students will laugh at me when I speak the English language. & 21 & 70 & 2.50 & 1.196 \\
\hline
\end{tabular}

As stated above in table 6, statements 4 and 9 recorded the same mean value which is 2.37 with Standard Deviation of 1.129 and 1.033 respectively. They keep thinking that the other students are better at speaking, and they get upset when they do not understand the corrections made by the teacher. $70 \%$ of the participants with the mean of 2.10 agreed that it embarrasses them to volunteer answers in English language class. Similarly, $60 \%$ of the participants with the mean of 2.57 $(\mathrm{SD}=1.073)$ feel that, their heart pounding when they are going to be called on in English language class and $67 \%$ of them feel that the other students speak English better than they do. Besides that, 70\% of them with the mean of $2.50(\mathrm{SD}=1.196)$ agreed that the other students will laugh at them when they speak the English language. As such, an average of $66 \%$ of participants evaluated themselves negatively when it comes to speaking English language.

Since the presence of anxiety has been proven, it was then used to investigate the correlation between the independent and dependent variable which are anxiety and speaking skills. 
Table 7. Correlation between anxiety and pre-test scores

\begin{tabular}{|c|c|c|c|}
\hline \multicolumn{4}{|c|}{ Correlations } \\
\hline & & Anxiety & Pre-test \\
\hline \multirow{3}{*}{ Anxiety } & Pearson Correlation & 1 & -.828 \\
\hline & Sig. (2-tailed) & & .000 \\
\hline & $\mathrm{N}$ & 30 & 30 \\
\hline \multirow{3}{*}{ Pre-test } & Pearson Correlation & -.828 & 1 \\
\hline & Sig. (2-tailed) & .000 & \\
\hline & $\mathrm{N}$ & 30 & 30 \\
\hline
\end{tabular}

** Correlation is significant at the 0.01 level (2-tailed).

From the statistical results as shown in table 7 above, the anxiety variable has a correlation coefficient with Pre-test scores of -.828. This indicates the existence of a strong negative relationship between these two variables: as anxiety increases, pre-test scores decrease. The second half of the correlations table does the same thing in reverse. It gives the correlation coefficient for pre-test scores against anxiety, which is -.828. Pre-test scores are also correlated with itself, which produces a perfect correlation of 1.000 .

Hence, it can be concluded that the presence of anxiety affected the bands obtained by the participants. In order to investigate the effects of task -based approach on ESL learners speaking anxiety, hypotheses below were formed:

$\mathrm{H}_{0}$ : There is no significant difference between the mean score of pre-test and mean score of post- test. $\left(\mathrm{H}_{0}: \mu_{1}-\mu_{2}=0\right)$

$\mathrm{H}_{1}$ : There is a significant difference between the mean score of pre-test and mean score of post- test. $\left(\mathrm{H}_{1}: \mu_{1}-\mu_{2} \neq 0\right)$

Table 8. Descriptive statistics of scores

\begin{tabular}{c|c|c|c|c|c|c}
\hline & & $\mathrm{N}$ & Minimum & Maximum & Mean & SD \\
\hline \multirow{2}{*}{ Fluency } & Pre-test & 30 & 2.00 & 4.00 & 2.6333 & .55605 \\
\cline { 2 - 7 } & Post-test & 30 & 3.00 & 7.00 & 4.6667 & .99424 \\
\hline \multirow{3}{*}{ Coherence } & Pre-test & 30 & 2.00 & 4.00 & 2.7667 & .72793 \\
\cline { 2 - 7 } & Post-test & 30 & 3.00 & 7.00 & 4.7000 & .91539 \\
\hline \multirow{2}{*}{ Grammar } & Pre-test & 30 & 2.00 & 4.00 & 2.9333 & .63968 \\
\cline { 2 - 7 } & Post-test & 30 & 4.00 & 7.00 & 5.0000 & .78784 \\
\hline \multirow{2}{*}{ Sentence } & Pre-test & 30 & 2.00 & 4.00 & 2.9333 & .63968 \\
\cline { 2 - 7 } & Post-test & 30 & 4.00 & 7.00 & 5.0000 & .78784 \\
\hline \multirow{2}{*}{ Vocabulary } & Pre-test & 30 & 2.00 & 4.00 & 2.8667 & .57135 \\
\cline { 2 - 7 } & Post-test & 30 & 3.00 & 6.00 & 4.6333 & .92786 \\
\hline \multirow{2}{*}{ Pronunciation } & Pre-test & 30 & 2.00 & 4.00 & 2.7333 & .52083 \\
\cline { 2 - 7 } & Post-test & 30 & 3.00 & 6.00 & 4.6667 & .92227 \\
\hline
\end{tabular}

The table 8 above shows descriptive statistics of bands scored by the participants in the pre and post-test. The participants were assessed based on their fluency, coherence, grammar, sentence structure, vocabulary and pronunciation as shown in the table above. The overall mean scores indicate that, there is a noticeable improvement shown by the participants after the seven weeks of Intensive English Programme.

Table 9. Paired Samples Statistics

\begin{tabular}{l|c|c|c|c|c}
\hline & & Mean & $\mathrm{N}$ & SD. & Std. Error Mean \\
\hline \multirow{3}{*}{ Pair 1 } & Pre-test & 2.80 & 30 & .66436 & .12130 \\
\cline { 2 - 7 } & Post-test & 4.77 & 30 & .93626 & .17075 \\
\hline
\end{tabular}

The table 9 above shows paired samples statistics for the mean scores of pre-test and post-test. The mean scores of pre-test is 2.80 with a standard deviation of 0.664 , and the mean scores of post-test is 4.77 with a standard deviation of 0.936. In other words, the average score for pre-test is in the range of band 2 to band 3 . On the other hand, the average score for post-test is in the range of band 4 to band 5. The mean scores of post-test are higher than the mean scores of pre-test. Hence, there is a significant difference between the mean scores of pre-test and post-test. 
Table 10. Paired Differences

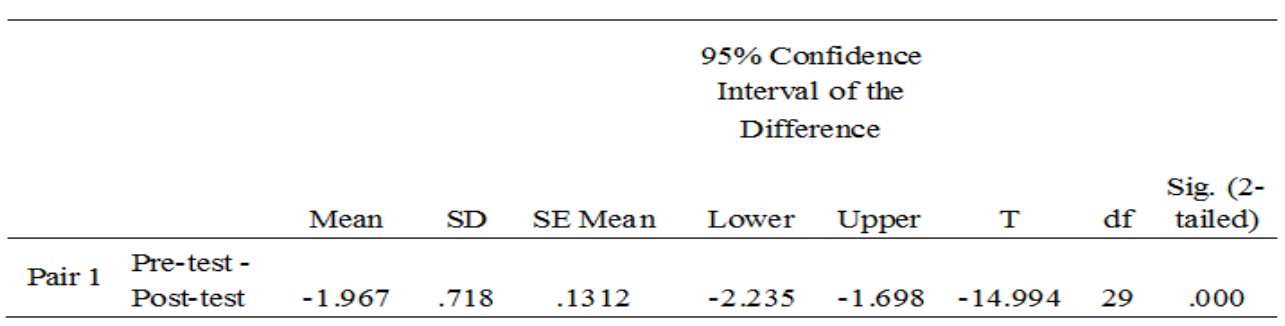

Table 10 above illustrates paired differences of pre and post-test mean scores. The mean difference is calculated as -1.967 , and the estimated t-test value is -14.994 . Since the probability value is (.000) less than alpha which is $(\alpha / 2=.005)$, the null hypothesis is strongly rejected.

The lower limit of estimate is -2.235 while the upper limit is -1.698 . Since the interval does not include the value of 0 , we can conclude that the difference in the pre-test and post-test scores is not zero. In other words, the use of Task-based approach in the ESL classroom has given a positive impact on the learners' speaking test scores. This conclusion is made based on the significant level of, $\alpha=0.01(1 \%)$ or Confidence level of $95 \%$.

Engeström's (2005) concept of activity system which integrates a methodology enabled the researcher to use task-based approach successfully. According to Engeström (2005), task-based approach clearly defines the role of the teacher and students and the influence of instruments/tasks in achieving desired outcome. The results of the analyses above have proven the effectiveness of Engeström's (2005) theory of pedagogy in ESL classroom.

\section{Discussion}

The overall findings revealed that the ESL learners who participated in this study experienced speaking anxiety in the classroom. Although this study mainly focuses on speaking anxiety/ communication apprehension, attention was given to the other two components of Language Anxiety, which are English language class anxiety and negative evaluation as they indeed contribute to the presence of anxiety among ESL learners (Horwitz, Horwitz $\&$ Cope, 1986). A total of $63 \%$ to $80 \%$ of the participants admitted that they possess less self-confidence and get panicked and nervous when they are asked to speak without any preparation in English language classroom in front of other students. Speaking with native speakers or being in an environment with native speakers often creates uncomfortable situations to these learners. This is due to the less exposure towards the usage of English language in the classroom or outside of the classroom.

Majority of the students agreed that they often feel like not going to their English language class. According to Mamhot et al. (2013), low self-perception, unconducive and unfriendly learning environment are some of the factors, which made them refuse to attend English language classes. Being frightened when they do not understand what the teacher says in English language and forgetting things that they know due to nervousness are the two important phenomena which teachers have to pay more attention. This usually occurs when the learners feel the environment is unsafe or threatening to them. Feeling pressured about the preparation for language class and overwhelming by the number of rules prevents learners from looking forward for the class.

On the other hand, due to negative evaluation, most of the participants felt embarrassing to volunteer answers; they felt others speak better than they do and afraid that other students will laugh at them if they speak English. These are among the statements which were highly agreed by the participants. The presence of such anxiety disabled them from acquiring sufficient speaking experience.

Therefore, the researcher has tested one specific pedagogical approach to investigate whether task-based approach reduces speaking anxiety among ESL learners. To be specific, the approach was adopted by the researcher to use meaningful real-world tasks which focus on the outcome (Skehan, 1996). Such tasks require learners to process language pragmatically to achieve an outcome (Ellis, 2003). In addition, according to Nunan (2005) pedagogical tasks involve language use for interaction which is different from grammatical exercises. Based on these references, the researcher designed various types of tasks to enable the learners to use the target language to complete the given tasks.

To be specific, the lessons were carried out in three phases: pre-task, task cycle and post-task (Willis, 1996). During pre-task, topics were introduced to create participants' interest by activating topic related words, phrases and sentences. For instance, in order to enable learners to use imperatives and prepositions of place (sit here/move to the left/put your hand in shoulder), a real-world interactive activity was carried out during the intervention period. During pre-task, teacher divided the class into groups of six which contained one photographer and five subjects. Teacher chose one student from each group as the (chief) photographer and gave him/her copy of a photo. They were not allowed to show the copy of the photo to the rest of the group. During task cycle students 
worked in groups to achieve the goal of the task. So, the photographer arranged the five subjects in the group into exactly the same positions as in the photograph, using only spoken words without using any gestures. During post-task, teacher allowed the subjects to look at the photo and discussed the most difficult pose to get right. This provided an opportunity for them to analyse some of the specific features of the language which occurred naturally during the task (Willis, 1996).

Such real-life activity created a fun learning environment which enabled learners to move around freely without anxiety. The more they were engaged in such activities, the less anxious they felt and consequently the outcome of every lesson was achieved. Subsequently, it created a safe and friendly environment which reduced speaking anxiety. In fact, Worde (2003) suggested that, teachers should create a relaxed atmosphere for starters and incorporate topics which interest the students. During these seven weeks of intervention rules were integrated in task-based activities.

For instance, an English song lyric which is 'Win the Race' by Modern Talking Feat was used as one of the tasks to enhance learners' pronunciation as well as to enrich their knowledge of simple future tense. During Pre-task, the learners were given some input of simple future tense; the use of 'will' and 'going to' was taught. During task, the learners were given task sheets which contain the lyric of 'Win the Race'. As they listened to the song, they had to fill in the blanks with the right words. The song was played twice, and then the answers were checked as a whole class. The third time the learners were instructed to sing the song along the music. The post-task phase enabled the teacher to stress on their pronunciation of 'you will' and 'you'll'.

"Guide the blind" was one of the activities which encouraged learners' participation. During the pre-task phase, the learners were given some input on simple present tense. The teacher wrote example instructions on the board and discussed with students. During the task the students were divided into two groups. Each group selected one representative and blind folded them. The blindfolded students were sent to the back of classroom. Group members guided the blindfolded students by giving verbal instructions to pick up the right stationary from the floor.

For instance, "Walk straight", "stop", "turn around", "move two steps forward" and so on. The blindfolded students were allowed to ask questions and clarifications to ensure that they are guided correctly. During the post-task, teacher randomly picked up some of the instructions which were directly translated such as "walk some more", "move front" and so on and wrote on the board. Corrections were made for the example instructions which were written on the board such as "walk further" and "move forward".

Various kinds of other task-based activities were conducted bearing in mind that not all learners are alike. Brown (2001:134) stated that "No one can be neatly pigeon-holed into a cognitive type". This was found through the teacher's observation when the learners were working on the tasks. The learners felt less pressure when they make positive statements, work in pairs or groups, complete tasks related to real-life context and equal treatment given to all of them. In fact, they were less anxious after knowing that the other learners were also at the same proficiency level.

This exposure had given positive impact on the students' results. Students who initially had lengthy pauses before most words improved their fluency by maintaining their flow of speech to keep going. Those who had insufficient vocabulary and uttered isolated words or memorised utterances in the pre-test, managed to talk about familiar and unfamiliar topics with a wide range of vocabulary in the post-test. This shows that the exposure towards the target language through various types of meaningful real-life interactive activities enriched their lexical resource and pronunciation. The integration of grammatical components with the tasks, has given an opportunity for participants to apply them in appropriate circumstances.

Various kinds of task-based activities were conducted bearing in mind that not all learners are alike. Brown (2001:134) stated that "no one can be neatly pigeon-holed into a cognitive type". This was found through the teacher's observation when the learners were working on the tasks. The learners felt less pressure when they make positive statements, work in pairs or groups, complete tasks related to real-life context and equal treatment given to all of them. In fact, they were less anxious after knowing that the other learners were also at the same proficiency level.

\section{Conclusions}

Educators and teachers believe that anxiety has an undeniable impact on learners' speaking skills. This has been proven through the findings of this study which revealed that anxiety exist among the learners in terms of communication apprehension, English language class anxiety and fear of negative evaluation. As a consequence, anxiety has become a hindrance to the development of speaking competency of many learners. The more anxious the learners became, the lower the grades were achieved. This was proven when the finding of the analysis showed that, there is a strong negative relationship between language anxiety and speaking skills among ESL low proficiency students.

In addition, this research indeed identified the effects of task-based approach on learners' speaking anxiety. The use of task-based approach throughout the intervention has given positive effect on the grades achieved in the post-test. This can be observed in the bands achieved by the participants in pre and post-test. The overall range of bands achieved by the participants in pre-test from band 2, 3 and 4 increased up to band 3, 4, 5 and 6 in post-test. 
As a conclusion, the use of various types of tasks in the English language classroom leads to effective teaching and learning environment. Task-based approach increases learners' participation because each task provides the learner new experience and opportunities to use the target language in their daily conversations. Therefore, teachers should adopt task-based approach in their ESL classroom to meet the immediate needs of the learners.

\section{Recommendations}

This study only tested one type of pedagogical approach which is task-based approach to reduce learners' speaking anxiety. The outcome of the chosen approach will be different from other type of pedagogical approaches. Hence, it would be a great contribution to the knowledge of second language acquisition if future researchers study further on various types of pedagogical approaches and their effects on ESL learners' anxiety in other skills such as writing, reading and listening.

Besides that, future research can also be done through observations and interviews. Observing learners performing different type of speaking tasks are essential to identify other barriers which hinder their performance in the English language classroom. However, not all the barriers can be identified through observations. Hence, interviewing the learners' will reveal more comprehensible information and enable the researchers to support their findings.

\section{Limitation of Study}

The researcher intends to test only one type of pedagogical approach which is task-based approach to remove learners' speaking anxiety. The outcome of the chosen approach will be different from other type of pedagogical approaches.

Besides that, same set of questions were used during pre and post-tests in this study. The results of the analysis will differ from this study if different set of questions were used for pre and post-tests. Hence, this limits the scope of study.

\section{REFERENCES}

[1] Abdullah, K. I. \& Rahman, N. L. A. (2010). A Study on Second Language Speaking Anxiety among UTM Students.

[2] Al-Sibai, D. M. (2005). L2 Anxiety of Saudi female university students enrolled in speaking courses.

[3] Amorim, R. M. (2013). Transforming Passive Listeners into Active Speakers: A study with Portuguese Undergraduates in 'English for the social sciences'. English Language Teaching, Vol.6, No.4.
[4] Andrade, M. \& Williams, K. (2009). Foreign Language Learning Anxiety in Japanese EFL University Classes: Physical, Emotional, Expressive, and Verbal Reactions. Sopia Junior College Faculty Journal, Vol.29, 1-24.

[5] Arnaiz, P. (2012). Foreign Language Anxiety in a Spanish University Setting: Interpersonal Differences. 17(1), 5-26. Revista de Psicodidactica, 17(1),5-26.

[6] Azabdaftari, B. (2013). On the Implications of Vygotskian Concepts for Second Language Teaching . Iranian Journal of Language Teaching Research.

[7] Brown, H. D. (2001). Principles of Language Learning and Teaching. New York: Longman.

[8] Brown, J. D., \& Rodgers, T. S. (2002). Doing Second Language Research. Oxford Handbooks for Language Teachers, 212.

[9] Chan Swee Heng, Ain Nadzimah Abdullah, Nurkarimah Binti Yusof. (2012). Investigating the Construct of Anxiety in Relation to Speaking Skills among ESL Tertiary Learners. The Southeast Asian Journal of English Language Studies, Vol 18(3):155-166.

[10] Chan, D. Y., \&. Wu, G. (2004). A study of Foreign Language Anxiety of EFL Elementary School Students in Taipei County. Journal of National Taipei Teachers College, 17(2),287-320).

[11] Cheng, R. (2012). Language Anxiety: Experiences of Chinese Graduate Students at U.S Higher Institutions. Journal of studies in International Education, 16(5) 477-497.

[12] Cheng, Y. S. (2004). A Measure of Second Language Writing Anxiety:Scale Development and Preliminary Validation. Journal of Second Language Writing, 313-335.

[13] Curran, C. A. (1972). Counseling-Learning: A Whole Person Model for Education. New York: Grune \& Stratton.

[14] Daly, J. A. (1991). Understanding communication apprehension: An introduction for language educators. In E. K. Horwitz \& D. J. Young (Eds.), Language anxiety: From theory and research to classroom implications (pp. 3-13). Englewood Cliffs, NJ: Prentice Hall.

[15] Diao. Z., \& Shamala. P. (2013). Anxiety of Speaking English in Class among International Students in a Malaysian University. International Journal of Education and Research, Vol.1 No.11.

[16] Daniels, H. (2001). Vygotsky and Pedagogy. London: Routledge.

[17] Dulay, H. and Burt, M. (1977) "Viewpoints on English as a Second Language” New York: Regents, 95-126

[18] Ellis, R. (2003). Task-based Language Learning and Teaching. New York: Oxford University Press.

[19] Engeström, Y. (1987). Learning by expanding: An activity-theoretical approach to developmental research. Helsinki: Orienta-Konsultit Oy.

[20] Engeström, Y. (1991). Non scolae sed vitae discimus: Toward overcoming the encapsulation of school learning. Learning and instruction, 243-259. 
[21] Engeström, Y. (2005). Developmental work research: Expanding activity theory in practice. Berlin: Lehmanns Media.

[22] Estaire, S. \& Zanon, J. (1994). Planning Classwork: A Task Based Approach. Oxford: Heinemann.

[23] Gardner, R. C. \& MacIntyre, P. D. (1993). A student's contribution to Second Language Learning: Part II, Affective Factors. Language Teaching, 26, 1-11.

[24] Gomari, H. \& Lucas, R. I. (2013). Foreign Language Learning Motivation and Anxiety among Iranian Students in the Philippines. Academic Journal.

[25] Hadi, A. (2013). Perception of Task-based Language Teaching: A study of Iranian EFL learners. English Language Teaching, Vol. 6, No. 1.

[26] Hamouda, A. (2013). An Exploration of Causes of Saudi Students' Reluctance to Participate in the English Language Classroom. International Journal of English Language Education, Vol.1, No.1.

[27] Horwitz, E.K, Horwitz, M.B, \& Cope, J. (1986). Foreign language classroom anxiety. . The Modern Language Journal, 70(2), 125-132.

[28] Krashen, S. (1985). The Input Hypothesis. London: Longman. (Krashen, Foreign Language Education: The Easy Way, 1997)

[29] Lee, J. F. (2000). Tasks and Communicating in Language Classrooms. McGraw-Hill Higher Education.

[30] Leontiev, A. N. (1981). The Problem of Activity in Psychology. In Wertsch, J.V. (Ed.). The concept of activity in Soviet psychology. Armonk, N.Y: M.E. Sharpe.

[31] Liu, S. F. (2007). Anxiety in the Foreign Language Classroom: An empirical study of foreign language anxiety experienced by a group of Australian university students studying spoken Chinese.

[32] Lucas, R. I., Miraflores, E. \& Go, D. (2011). English Language Learning Anxiety among foreign language learners in the philippines. Philippine ESL Journals, Vol. 7.

[33] Mak, B. (2011). An exploration of speaking-in-class anxiety with Chinese ESL learners. System39, 202-214.

[34] McCroskey, J. C. (1987). Willingness to communicate. In J.C. McCroskey \& J. A. Daly (Eds.), Personality and interpersonal communication (pp. 129-156). Thousand Oaks, CA: Sage.

[35] McIntyre, P.D \& Gardner, R. C. (1989). Anxiety and Second Language Learning: toward a theoretical clarification. Language learning, 251-275.

[36] Mamhot, A. M., Martin, M. H. \& Masangnya, E. M. (2013). A Comparative Study on the Language Anxiety of ESL and EFL learners. . Philippine ESL Journal, Vol.10.

[37] Musa, N. C. , Lie, K. Y. \& Azman, H. (2012). Exploring English Language learning and Teaching in Malaysia. Journal of Language Studies.

[38] Moore, P. J. (2018). Task-based Language Teaching. TESOL Encyclopedia of English Language Teaching.

[39] Nunan, D. (2005). Important tasks of English education:
Asia-wide and beyond. Asian EFL Journal, 7(3).

[40] Nunan, D. (2006). Task-Based Language Teaching in the Asian Context: Defining 'Task'. Asian EFL Journal , 10. 8 (3).

[41] Prabhu, N. S. (1987). Second Language Pedagogy. Oxford: Oxford University Press.

[42] Richards, J. C. (2008). Developing Classroom Speaking Activities; from Theory to Practice.

[43] Richards, J. C. (1990). Conversationally Speaking: Approaches to the Teaching of Conversation. In J. C. Richards, The Language Teaching Matrix (pp. 67- 86). New York: Cambridge University Press.

[44] Richards, J.C. \& Rodgers, T. (2011). Approaches and Methods in Language Teaching. New York: NY: Cambridge.

[45] Scovel, T. (1978). The effect of foreign language learning: A review of the anxiety research. . Language Learning, 129-142.

[46] Skehan, P. 1996. A framework for the implementation of task-based instruction. Applied Linguistics 17: 38-62.

[47] Spielberger, C. D. (1966). Theory and research on anxiety. In. C.D. Spielberger (Ed.). Anxiety and behaviour . New York: Academic Press., 3-20.

[48] Tanveer, M. (August 2007). Investigation of the factors that cause language anxiety for ESL/EFL learners in learning speaking skills and the influence it casts on communication in the target language. Doctoral dissertation, University of Glasgow.

[49] Tartar, S. (2005). Why keep silent? The classroom participation experiences of non-native-English-speaking students. Language and Intercultural Communication, 5, 284-293.

[50] Vizayaletchumi, P. R. (2012). An empirical Study on Alleviating Speaking Anxiety among Iranian EFL Students via Drama Techniques. Thesis Ph.D, 72.

[51] Vygotsky, L. S. (1978). Mind in Society: Interaction between learning and development. Cambridge: MA: Harvard University Press.

[52] Watson, D., \& R. Friend. 1969. Measurement of social-evaluative anxiety. Journal of consulting and clinical psychology 33(4): 448-457.

[53] Willis, J. (1996). A Framework for Task-Based Learning. Harlow: Longman.

[54] Wörde, R. V. (2003). Students' Perspectives on Foreign Language Anxiety. Virginia Community College System, Vol. 8 No. 1.

[55] Young, D.J. (1990). An investigation of students' perspectives on anxiety and speaking. Foreign Language Annal, 23(6), 539-553. 